\title{
Mine Action in Afghanistan
}

\author{
William Maley
}

\begin{abstract}
Afghanistan is severely contaminated by anti-personnel mines, which pose major physical, social and economic threats to repatriating refugees. Fortunately, mine action-a multidimensional effort to address these problems through survey, detection, clearance, mineawareness, and victim assistance-is well developed in Afghanistan, with the Afghan Mine Action Program a model of good practice. That said, mine action faces ongoing challenges, of which those originating in the realm of politics are the most troubling.
\end{abstract}

\section{Précis}

L'Afghanistan est profondément infesté demines anti-personnelles, et ces dernières représentent un danger physique, social et économique majeur pour le rapatriement des réfugiés. Fort heureusement, ce quel'on pourrait nommer l'action au déminage (mine action) est très bien développé en Afghanistan. Il s'agit $d$ 'un effort multidimensionnel visant d traiter ce probleme par le biais de fouilles sur le terrain, détection, élimination, conscientisation des populations face au danger représenté par les mines, et aide aux victimes. Le programmed'actionau déminage afghan apparaît comme un modele du genre. Cependant, l'action au déminage fait face à des remises en question importantes, au nombre desquelles celles se dégageant des arcanes de la politique ne sont pas les moins troublantes.

William Maley, Ph.D., is a Senior Lecturer in Politics, University College, University of New South Wales, Australia. He has been a Visiting Research Fellow at the Refugee Studies Programme at Oxford University, and he has edited Dealing with Mines: Strategies for Peacekeepers, Aid Agencies and the International Community (Canberra: Australian Defence Studies Centre, 1994) and Fundamentalism Reborn? Afghanistan and the Taliban (New York: New York University Press, 1998).
On the evening of 27 December 1979, Soviet special forces stormed the Tajbeg Palace in southern Kabul and killed its most prominent occupant, the Afghan President Hafizullah Amin. Almost immediately, they swathed the Palace with minefields. The Soviets, and indeed the Soviet Union, are now gone, but their mines remain. From this gruesome starting point, mines were laid in many other parts of the country so that nearly two decades later, Afghanistan remains one of the countries most severely afflicted by this vicious form of late twentieth century pollution. Remarkable steps have been taken to address the problem. However, for too many Afghans, not least among them those Afghan refugees who remain stranded in Pakistan and Iran, the threat of hideous injury from landmines continues to thwart their hopes of return to their homeland. In the following remarks, I propose to examine five topics: the nature of the landmine menace, ways of addressing the problem, the evolution of "mine action" in Afghanistan, the achievements of the Mine Action Program, and the challenges which continue to face mine action in Afghanistan.

\section{The Problem of Landmines}

A mine is a munition placed under, on or near the ground or other surface area which is designed to be exploded by the presence, proximity or contact of a person or vehicle. Mines generally fall into two categories, Anti-Tank Mines (ATMs) and Anti-Personnel Mines (APMs). A neat distinction tends to break down when one encounters ATMs with anti-handling devices, which in practice can have similar effects to APMs. The key feature of mines is that they are victim-activated, and this accounts for the massive concern which has arisen about their effects. In too many conflicts, including the Afghan conflict, the bulk of victims have been civilian non-combatants. This has prompted widespread debate as to their legitimacy as a weapon (Human Rights Watch 1993; Davies 1994; McGrath 1994; Cahill 1995; Roberts and Williams 1995; ICRC 1996).

The effects of landmines can be widespread and horrific. Even simple movement from one place to another can be fraught with danger: in April 1992, after the collapse of Najibullah's communist regime, the largest and fastest voluntary repatriation of refugees in UNHCR's history was blighted by a sharp upsurge in recorded mine injuries (Coupland 1996). Mines, according to the International Committee of the Red Cross, "have the power to deny, by their very presence, the fundamental right of refugees to return to their native lands" (ICRC1992,8). The most immediateconsequences of APMs are medical, and vary according to whether the APMs in question are blast or fragmentation mines, with the former causing injury through the expansion of heated gases and the latter through the dispersal of shrapnel (ICRC 1995). An Afghan who treads on a blast mine may well die on the spot, and even if he or she survives, is likely to lose one or both legs. Infection is a serious riskbecause of the amount of foreign matter that is embedded in the tissues of the victim (Coupland 1992). Theneed for prostheses, if victims are to recover mobility, points to a further problem: that of coping with a lifelong disability. Afghanistan is not a society well-equipped to meet the needs of the disabled (Miles 1990). As a result, mine victims are likely to suffer a disastrous loss of self-esteem and to lapse intoclinical depression, for which the resources to provide treatment are again pitifully inadequate. Thus, landmines have significant social consequences. They also have striking economic consequences, since the presence of APMs can deny the use of land to those who need it for agricultural or pastoral purposes. And 
those who feel they have no option but to make use of land are often taking a terrifying risk in doing so, something driven home to this writer when he watched a shepherd lead a flock of sheep through a clearly-marked minefield south of Kabul in June 1997. Finally, mines are an environmental disaster, something which the Society of Afghan Volunteer Environmentalists (SAVE) headed by Abdul Wajid Adil has highlighted.

Calculating the scale of Afghanistan's landmine problem is a complex task. At least 38 different types of mines have been found in Afghanistan. On occasion, estimates of the number of mines to be found have been put forward: for example, in 1993 the UN suggested a total of ten million mines and items of unexploded ordnance (UNOCHA 1993, 2). However, the simple number of mines in a country is a poor measure of the problems they cause, since it tells one nothing about the pattern of their distribution and the resultant human, social and economic effects. It is more useful to map and count minefields, since a minefield will disrupt normal life irrespective of how many mines it contains. Initial data became available in 1993 as a result of the National Survey of Mines Situation in Afghanistan (MCPA 1993)-2,353 minefields were identified, occupying 388.75 square kilometres, or 0.06 percent of Afghanistan's area. However, only 46.21 square kilometres were designated as requiring " $h$ igh priority clearance," since many minefields were located on mountain tops, hillsides and desert-areas to which the Soviet Union wished to deny its opponents access for transit purposes, but which were not central to the lives of many Afghans. Subsequent surveys haveidentified further minefields to be cleared. In addition, the tasks of mine action have expanded to cover the problem of "battlefield area clearance," as the sedentary population, returning refugees, and internally displaced persons increasingly encounter threats not simply from mines but from unexploded bombs and other ordnance left over from battle. Thus, at the beginning of 1998, it was concluded that 725 square kilometres of land remained affected by mines, with 324 square kilometres demanding high priority clearance. High priority areas for clearance were found in the provinces of Herat (73.22 sq km), Kandahar (59.28 sq km), Farah (41.05 sq km), Paktia (33.15 sq km), Zabul (19.02 sq km),Kabul(18.81 sq km), Ghazni(18.34 sq km), Paktika (14.48 sq km), and Nimruz (10.73 sq km). More happily, in Jowzjan, Bamian and Uruzgan, no high priority minefields remained. (UNOCHA 1998a, 20). Mine clearance remains a substantial task. Fortunately, it is not significantly complicated by remining of cleared areas, of which there is evidence only in the Shomali Valley.

\section{Techniques of Mine Action}

Some years ago, talk of "mine clearance" or "demining" was commonplace. These terms still are useful as labels for particular types of activity. To describe the totality of steps to address the problem of APMs, the broader term "mineaction" is becoming increasingly popular. It captures the interconnectedness of the complex steps that are required to address a complex problem. Afghanistan offers an excellent example of a complex mine action program at work. Mine action incorporates five key elements: survey, detection, clearance, mine awareness training, and victim assistance. Prioritizing different spheres of mine action is a highly contentious issue amongst professionals in the area, and can become a source of significant disputation if not handled with sensitivity.

Surveys of potentially mined areas are vital if scarce resources are to be used efficiently. It is at the survey stage that minefields are initially marked. First, it is necessary to undertake general surveys, to identify the areas which locals believe to be mined, and to identify the use to which mined land could be put if cleared. This enables priorities to be attached to the clearance of different areas. These must be followed by technical surveys, in which the exact boundaries of minefields are traced (in Afghanistan by Global Positioning System methods) and detailed maps prepared which can be passed on to deminers. Finally, completion surveys bring the demining process to an end.

Detection of landmines is one of the most challenging technical tasks of humanitarian mine action. A very high level of reliability is required, certainly more than in military mine clearance. In the latter the objective is often to breach a path rather than clear an entire area, and a higher level of casualties may be deemed acceptable given the intrinsic risks associated with war. Metal detectors are widely used. However, it can be difficult to use them to detect those APMs, which are made largely of plastic and have low metallic signatures, especially if soil has a high ferrous content. Metal detectors are thus being increasingly augmented by the use of dogs trained to detect with their sensitive noses the explosive charges within mines. A great deal of research on alternativemeans of detection-for example, ground-penetrating radars, biosensors, and infrared detection techniques-is being conducted, but there is a considerablegulf between what appears promising in the hands of physicists in a well-equipped laboratory and what will prove workable in the potentially harsh terrain of a mine-infested Third World country such as Afghanistan where physicists are in short supply.

Clearance for the most part is carried out in a laboriously manual fashion. If simple metal detectors are being used in the initial sweep of what is known to be a mined area, progress can be agonizingly slow, since shrapnel, bullet casings, and other detritus of battle, as well as scrap metal, may all give positive readings and require investigation. This typically involves a deminer with a prodder clearing away surrounding soil to reveal the precise nature of the object detected. In Afghanistan, standard operating procedures require that mines be blown up in situ with plastic explosives, a procedure that allays any suspicion that mines are being lifted for reuse. Mechanical mine clearance vehicles using flails-which beat the earth in or on which mines are to be foundhave been developed, but their utility in Afghanistan is limited by the nature of 
the terrain. Battlefield clearance requires somewhat different techniques, since some UXOsmay need tobemoved before they can be safely exploded. An old firing range at Pul-e Charkhi on the eastern outskirts of Kabul is used for such controlled detonations.

Mine awareness is a vital activity, but one of the most troublesome. Poorly executed or culturally-insensitive mine awareness training can waste scarce resources, and-in the worst instances-be counterproductive. Mine awareness training needs to be carefully targeted to groups at greatest risk. It is also important that mine awareness classes not inadvertently become a venue to further degrade the self-esteem and psychosocial wellness of mine victims. At a number of classes in Afghanistan attended by the author over the years, traumatized mine victims were forced to relive the worst experiences of their lives. Particular problems arise in Afghanistan because of the vulnerability of pastoral nomads, whose lifestyle puts them at relatively high riskbut also makes them inaccessible to villagebased classes (MSF 1997, 24).

Finally, victim assistance is vital in a country as contaminated by APMs as Afghanistan. In the short term, this mostly involves surgery to craft from a smashed leg an amputation stump to which a prosthesis can be attached, together with rehabilitation training to allow victims to recover mobility. Other medical treatments may also be required, as mine injuries need notbelimited to the limbs. In the longer-run, however, victim assistance involves the provision of work opportunities to foster victim self-sufficiency and mostfundamentally of all, efforts to break down the cognitive barriers which define the disabled as being of limited worth. This is a great concern of the Afghan Disabled Society headed by Abdul Rahman Sahak. None of this is easy to deliver.

\section{The Organization of Mine Action in Afghanistan}

Mine action in Afghanistan has a venerablehistory. During the 1980 s, the problem of APMs was one with which members of the staffs of non-govern- mental organizations (NGOs) became distressingly familiar. The International Committee of the Red Cross operated a surgical hospital in Peshawar to which many mine accident victimsthe more fortunate ones-were transported from ICRC clinics on the Pakistan-Afghanistan border. However, concerted mine action had to await the signing of the Geneva Accords in April 1988, and more fundamentally, the completion of the withdrawal of Soviet troops from Afghanistan in February 1989. Enormous strides have been made in the decade since then, fundamentally because of the wisdom with which the program was initiated. Since contest for control of the state in Afghanistan persisted (Saikal and Maley 1991; Maley 1997), it was necessary to develop a model for mine action independent of Kabul-based bureaucracies. An initial experiment with camp-based training of villagers proved a failure: tools were sold in local markets, and documentation of both mine incidents and program achievements was poor (Eaton, Horwood, and Niland 1997, 1213). It was clear that mine action had to be put on a thoroughly professional footing. The model which was then adopted provided for mine action to be substantially undertaken by Afghan NGOs created for the purpose, but under the organizational umbrella of what was to become the United Nations Office for the Coordination of Humanitarian Assistance to Afghanistan (UNOCHA). This framework remains in place, and has been an outstanding success.

The UNOCHAMine Action Program for Afghanistan (MAPA) thus has a number of discrete elements. Its management heart is the UNOCHA Mine Action Centre for Afghanistan (MACA), based in Islamabad, Pakistan, with regional offices in Kabul, Jalalabad, Kandahar and Heart. MACA's headquarters are under the supervision of a Program Manager. In recent years, the position of Program Manager has been occupied by a succession of retired officers from the Australian Army who had earlier served in the area during the deployment from 1989 to 1993 of an Australian Army contingent that was attached to the UN program to provide technical advice and training to Afghan staff (Maley 1994). The implementation of the work of MAPA is in the hands of a range of NGOs, the majority of them Afghan; around 3,900 Afghans are employed by the program. Survey work is largely the responsibility of the Mine Clearance Planning Agency (MCPA). The bulk of actual detection and clearance is done by Afghan Technical Consultants (ATC), the Mine Detection Dog Centre (MDC), the Demining Agency for Afghanistan (DAFA), the Organization for Mine Clearance and Afghan Rehabilitation (OMAR), and the HALO Trust, which is a British charity. Awareness training is undertaken by OMAR, together with Handicap International (HI), Save the Children USA, the Afghan Red Crescent Society, and-in one of the most imaginative elements of the program-the BBC Drama Project(AEDP). The project conveysmine awareness messages through the medium of a soap opera, New Home, New Life, which is specially designed to convey useful information through dramatic form on short-wave radio. Victim assistance is a major activity of the International Committee of the Red Cross, which provides surgical facilities and runs world-renowned orthopaedic rehabilitation centres (Ignatieff 1998, 153-56).

The program is funded by voluntary donations, with Sweden, the USA, the Netherlands, Germany, Japan, the United Kingdom, and the European Union being notably generous contributors. MAPA-in contrast to some other areas of activity for which the UN has sought funding through its annual Consolidated Appeal-has been relatively well funded. For each of the last six years, over U.S.\$15 million has been subscribed to support MAPA's work, and by mid-1998, U.S.\$16,182,234 had been received or pledged for work during the current year (UNOCHA 1998b, 8). However, this still fell short of the Appeal target of U.S.\$23,985,000.

\section{Achievements}

Whathave been the main achievements of MAPA? They fall, I would argue, into 
three categories. The first relates to the concrete work of the program in Afghanistan. The second relates to the unintended consequences of the program in Afghanistan. The third relates to the contribution of the program to the broad river of world opinion which culminated in December 1997 in the signing of the Convention on the Prohibition of the Use, Stockpiling, Production and Transfer of Anti-Personnel Mines and on their Destruction, known as the Ottawa Treaty, which will come into effect in March 1999.

The concrete achievements of the program are considerable. As of November 1997, 184 square kilometres of mined land had been surveyed, mapped, and marked, 130 square kilometres of high priority mined land had been cleared, and 122 square kilometres of former battlefield land had been cleared of UXOs. In the process, 686,813 mines and UXOs had been destroyed. In addition, 3,863,377 Afghans had received mine awareness training. The program is also an efficient one: 1995-96 figures suggested an average clearance cost for manual teams of U.S.\$1 per square metre, which were "the lowest reported from any country" (Eaton, Horwood, and Niland 1997,39). One of the factors which has contributed to the efficiency of the program has been its exposure to a number of rigorous external evaluations, which have permitted significant gains to be made in both productivity and safety. This experience has highlighted an often-overlooked point of considerable importance-that much can be gained through improvement in management structures and techniques. Mine action is very much a human and social phenomenon, and while technological innovations can improve program efficiency, they areby no means the only way of lifting performance.

In addition to these achievements, MAPA has had a number of valuable unintended consequences. Perhaps most importantly, it has provided a venue in which Afghans of widely differing backgrounds can come together to further a cause which is universally recognized to be a beneficial one.
Deminers arehighly esteemed, and they have the opportunity to re-learn a number of sociopolitical skills which years of ferocious war tend to undermine. These include the skills of trusting and cooperating across ethnic lines. As ethnic tensions have sharpened in Afghanistan (Saikal 1998), the importance of mine action as a neutral venue for cooperation has increased. MAPA has also provided an example of what Afghan NGOs are capable of achieving. Apart from the Afghan Red Crescent Society, founded in 1934, NGOs were virtually unknown to Afghanistan until the years following the Soviet invasion. Following the Soviet withdrawal, the relative flood of money for reconstruction programs triggered a high level of rent seeking from Afghans. NGOs of dubious provenance emerged, which often amounted to no more than family networks fronted by polished salesmen operating out of briefcases. While the mine action NGOs have not been entirely free of informal networking-which can pervade almost any formal organization-they have nonetheless performed in a highly professional manner. At some point in the future, they may provide a prototype for further forms of autonomous social organization in Afghanistan. Finally, the mine action NGOs have nurtured some bright talent developed in exile by younger Afghans whomake up the technocratic stratum. At some point, the country will need their talent to exploit more widely for purposes of postwar reconstruction.

Mine action in Afghanistan has been brought to the attention of the wider world through the activities of the Afghan Campaign to Ban Landmines (ACBL), which was founded in August 1995. The Afghan Campaign is chaired by Sayed Aqa, who is also the Director of MCPA. The ACBLhas been an energetic member of the International Campaign to Ban Landmines (ICBL), which in 1997 was jointly awarded the Nobel Peace Prize. Since its establishment, the ACBL has gathered over 240,000 petitions calling for a total ban on landmines (ACBL 1998, 1). Through its work, ACBL has directly linked Af- ghanistan to the remarkable process, which resulted in the conclusion of the Ottawa Treaty (see Thakur 1998; English 1998; Price 1998). The Ottawa Treaty is not a magic solution to the landmines problem, but constitutes a powerful statement of moral revulsion against this particular weapon and has undoubtedly fostered a climate in which resources for mine action are more likely to be forthcoming. The United States's "Demining 2010" initiative may beone positivespin-off from the Ottawa process, since the US, while refusing to sign the treaty itself, has been keen to demonstrate to doubters that it remains committed to the cause of mine action. In thecontext of the Ottawa process, the ACBL has played a vital role in ensuring that the particular needs of Afghanistan are notdrowned out by the clamour of the wider world.

\section{Challenges}

Mine action nonetheless faces a number of serious challenges. The times in which we are living are not easy ones for any kind of humanitarian action in Afghanistan, and illustrate how complex is the interplay between politics and humanitarianism. The rise of the Taliban movement (see Maley 1998), while at heart a product of Pakistani military strategy, has created major problems for both the United Nations and Western and Afghan NGOs. The Taliban are unquestionably the world's least feminist movement. While their persecution of women (PHR 1998) has not impacted directly on mine clearance, since it is a gender neutral activity, it has affected mine awareness training in someareas. Moregenerally, ithas poisoned the climate for UN and NGO activity in Afghanistan.

The consequent disruptions in UN activities have struckMAPA as well. At the end of September 1997, the Head of the MAPA office in Kandahar, together with two other officials, was expelled by the Taliban after he "walked out of a meeting in protest after a female colleague was told to address the assembled company from behind a screen" (UNOCHA 1997, 1). On 23 March 1998, the UN ordered the withdrawal of all its 
expatriate staff from Kandahar following a physical assault on an expatriate staffer by the Taliban governor (Hussain 1998). This suspension of activities lowered MAPA's rate of clearance for the firsthalf of 1998 (UNOCHA 1998b, 9). In May 1998, a UN delegation visited Kabul to negotiate terms for reengagement, but the concession itmade in Article 13 of its Memorandum of Understanding with the Taliban that "women's access to and participation in health and education will need to be gradual" not only provoked a storm of protest from NGOs, but arguably encouraged the Taliban to make their subsequent demand that Western NGOs shift to the derelictPolytechnic complex. Most NGOs rightly interpreted this demand as a covert expulsion order that prevented any large-scale UN re-engagement from taking place. The departure of the NGOs was accompanied by Taliban theft of equipment, notably vehicles provided to the Sandy Gall Afghanistan Appeal by the Princess Diana Memorial Fund. As Agence France Presse reported on 24 July, the "two Diana memorial fund Land Rovers now ferry around turbaned and gun-toting passengers in comfort through the bumpy and potholed streets of Kabul." Finally, the murder in Kabul on $21 \mathrm{Au}$ gust 1998 of Lieutenant Colonel Carmine Calo, an Italian officer attached to the UNSpecial Mission to Afghanistan, prompted the withdrawal fromKabul of all expatriate UN staff including the Head of the MAPA office. It is likely to be some time before conditions permit the reintroduction of any significant expatriate presence.

There is one further challenge to be met. Afghanistan, despite being seriously afflicted by the scourge of APMs, is yet to sign the Ottawa Treaty. This may become a practical problem for MAPA should donors at some point decide to make it a condition of assistance that the state soliciting aid be a state party to the Convention. However, it is also regrettable from a symbolic point of view. The victims of mines in Afghanistan are overwhelmingly Afghan, and if the country's political leaders cannot come together to renounce a weapon by which their own people have been so hideously scarred, it speaks poorly of their claims to popular legitimacy.

\section{References}

Afghan Campaign to Ban Landmines (ACBL). 1998. “240,000 Afghans Support a Total Ban on Anti-Personnel Landmines." Ban Landmines 3, 1.

Cahill, Kevin M., ed. 1995. Clearing the Fields: Solutions to the Global Land Mines Crisis. New York: Basic Books.

Coupland, R. M. 1992. Amputation for War Wounds. Geneva: International Committee of the Red Cross.

Coupland, R. M. 1996. "The effects of weapons: surgical challenge and medical dilemma." Journal of the Royal College of Surgeons of Edinburgh 41, 65-71.

Davies, Paul.1994. War of the Mines: Cambodia, Landmines and the Impoverishment of a $\mathrm{Na}$ tion. London: Pluto Press.

Eaton, Robert, Chris Horwood, and Norah Niland. 1997. Afghanistan: The Development of Indigenous Mine Action Capacities. New York: Lessons Learned Unit, Department of Humanitarian Affairs, United Nations.

English, John. 1998. "The Ottawa Process: Paths Followed, Paths Ahead." Australian Journal of International Affairs 52, 121-32.

Human Rights Watch. 1993. Landmines: $A$ Deadly Legacy. New York: Human Rights Watch.

Hussain, Zahid. 1998. "UN forced out of Kandahar." The Times, 25 March.

Ignatieff, Michael. 1998. The Warrior's Honor: Ethnic Warand the Modern Conscience. London: Chatto \& Windus.

International Committee of the Red Cross (ICRC). 1992. Mines: A Perverse Use of Technology. Geneva: ICRC.

-1995. The Worldwide Epidemic of Landmine Injuries. Geneva: ICRC.

-1996. Anti-Personnel Landmines: Friend or Foe? Geneva:ICRC.

Maley, William. 1994. "Australia and Mine Clearance in Afghanistan." Dealing with Mines: Strategies for Peacekeepers, Aid Agencies and the International Community, edited by William Maley, 63-75. Canberra: Australian Defence Studies Centre.

- 1997. "The Dynamics of Regime Transition in Afghanistan." Central Asian Survey no. 16, 167-84.

Maley, William, ed. 1998. Fundamentalism Reborn?: Afghanistan and the Taliban. New York: New York University Press.

McGrath, Rae. 1994. Landmines: Legacy of Conflict. Oxford: Oxfam Publications.
Mine Clearance Planning Agency (MCPA). 1993. Report of the National Survey of Mines Situation: Afghanistan. Vols. I-II. Islamabad: MCPA.

Miles, Michael 1990. "Disability and Afghan Reconstruction: some policy issues." Disability, Handicap \& Society no. 5, 257-67.

Médecins Sans Frontières (MSF). 1997. Living in a Minefield: A Report on the Mine Problem in Afghanistan. Paris: Médecins Sans Frontières.

Physicians for Human Rights (PHR). 1998. The Taliban's War on Women: $A$ Health and Human Rights Crisis in Afghanistan. Boston: PHR.

Price, Richard. 1998. "Reversing the Gun Sights:Transnational Civil Society Targets Landmines." International Organization 52, 613-44.

Roberts, Shaun, and Jody Williams. 1995. After the Guns Fall Silent: The Enduring Legacy of Landmines. Washington DC: Vietnam Veterans of America Foundation.

Saikal, Amin, and William Maley. 1991. Regime Change in Afghanistan: Foreign Intervention and the Politics of Legitimacy. Boulder: Westview Press.

Saikal, Amin, 1998. "Afghanistan's Ethnic Conflict." Survival 40, 114-26.

Thakur, Ramesh. 1998. "Anti-Personnel Landmines." Pacifica Review 10, 61-68.

United Nations Office for the Coordination of Humanitarian Assistance to Afghanistan (UNOCHA). 1993. Afghanistan: Mine Clearance Programme for 1993. Islamabad: UNOCHA.

- 1997. Humanitarian Assistance for Afghanistan: Weekly Update No. 234. Islamabad: UNOCHA.

1998a. Afghanistan: Mine Action Programme Workplan 1998. Islamabad: UNOCHA.

_. 1998b. Afghanistan: Mid-Term Review of the 1998 Consolidated Appeal. Islamabad: UNOCHA. a

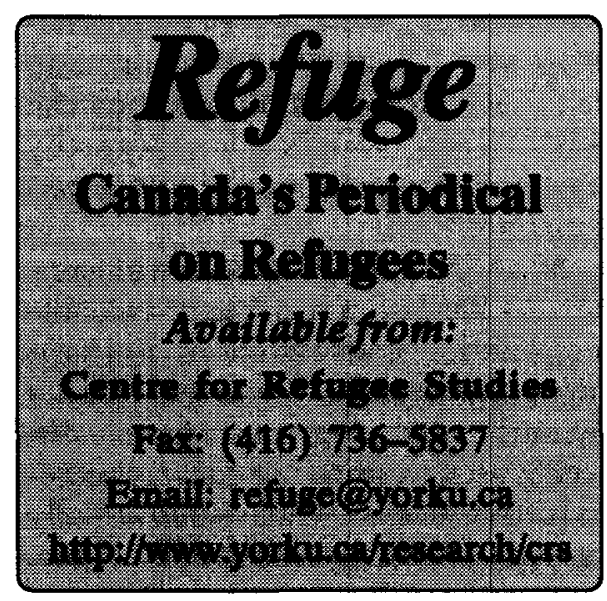

